DOI: https://doi.org/10.24127/ajpm.v10i1.3240

\title{
PENGEMBANGAN MEDIA PEMBELAJARAN MATEMATIKA MODEL BLENDED LEARNING BERBASIS MOODLE
}

\author{
Indah Riezky Pratiwi $^{1}$, Parulian Silalahi ${ }^{2}$ \\ ${ }^{1,2}$ Politeknik Manufaktur Negeri Bangka Belitung, Sungailiat, Indonesia \\ E-mail: $\quad$ indah_riezky@yahoo.com ${ }^{1)}$ \\ paruliansilalahi@gmail.com $^{2)}$
}

Received 13 November 2020; Received in revised form 24 February 2021; Accepted 08 April 2021

\begin{abstract}
Abstrak
Rendahnya ketersediaan media pembelajaran Matematika yang interaktif menjadi salah satu penyebab rendahkan prestasi mahasiswa dalam bidang Matematika. Penelitian ini bertujuan untuk Menghasilkan media pembelajaran dengan model Blended Learning berbasis MOODLE yang memenuhi kriteria valid dan praktis. Metode yang digunakan dalam penelitian ini adalah metode Research and Development (R\&D) dengan model ICCEE (Identification, Choose, Create, Engagement, Evaluation). Subjek dalam penelitian ini ada 55 orang mahasiswa Teknik Mesin di Politeknik Manufaktur Negeri Bangka Belitung. Teknik pengumpulan data yang digunakan dalam penelitian ini adalah lembar validasi ahli dan angket uji coba kepraktisanan media. Hasil penilaian dari 2 orang validator, menyatakan bahwa media valid dan siap diujicobakan. Berdasarkan uji coba kelompok kecil yang dilakukan terhadap 13 mahasiswa, diperoleh rata-rata skor 78,20, sedangkan uji coba kelompok besar yang dilakukan terhadap 55 mahasiswa memperoleh hasil 78,89. Hal ini memberikan kesimpulan bahwa media pembelajaran yang dikembangkan tergolong praktis. Berdasarkan data yang diperoleh, dapat disimpulkan bahwa media pembelajaran Matematika model Blended Learning berbasis MOODLE tergolong valid dan praktis. Dengan demikian media pembelajaran Matematika model Blended Learning berbasis MOODLE siap digunakan untuk penerapan pembelajaran Matematika di Politeknik Manufaktur Negeri Bangka Belitung.
\end{abstract}

Kata kunci: Blended learning; media; moodle; pembelajaran matematika.

\begin{abstract}
The low availability of interactive Mathematics learning media is one of the reasons for the lowering of student achievement in the field of Mathematics. This study aims to produce learning media with a MOODLE-based Blended Learning model that meets valid and practical criteria. The method used in this research is the Research and Development $(R \& D)$ method with the ICCEE model (Identification, Choose, Create, Engagement, Evaluation). The subjects in this study were 55 Mechanical Engineering students at the Bangka Belitung State Manufacturing Polytechnic. Data collection techniques used in this study were expert validation sheets and media practicality trial questionnaires. The results of the assessment of 2 validators stated that the media was valid and ready to be tested. Based on small group trials conducted on 13 students, an average score of 78.20 was obtained, while large group trials conducted on 55 students obtained a result of 78.89. This concludes that the learning media developed are practical. Based on the data obtained, it can be concluded that the learning media of the MOODLE-based Blended Learning model of Mathematics are classified as valid and practical. Thus, the learning media of the MOODLE-based Blended Learning model of mathematics are ready to be used for the application of Mathematics learning at the Bangka Belitung State Manufacturing Polytechnic.
\end{abstract}

Keywords: Blended learning; mathematics learning media; moodle; practical; valid

This is an open access article under the Creative Commons Attribution 4.0 International License

\section{PENDAHULUAN}

Kemajuan teknologi digital memiliki dampak yang luar biasa dalam pengajaran pedagogi dalam pendidikan tinggi dan pembelajaran siswa (Sahni, 2019). Wijayanti, dkk (2017) menjelaskan bahwa kompetensi Abad 21 juga menuntut agar peserta didik 
terlibat langsung dalam proses pembelajaran yang memanfaatkan fasilitas internet, dimana peserta didik bukan hanya sebatas mencari informasi, tapi peserta didik juga melaksanakan pembelajaran secara online. Dengan begitu keterampilan literasi TIK dan literasi informasi peserta didik akan tergali. Pendidikan yang dicirikan oleh pemanfaatan teknologi digital dalam proses pembelajaran dikenal dengan cyber system dan mampu membuat proses pembelajaran berlangsung tanpa batasan ruang dan waktu. Tipe pembelajaran yang mampu mengakomodir tantangan ini salah satunya adalah tipe Blended Learning. Karakteristik dari Blended Learning ini adalah adanya kombinasi pembelajaran tatap muka dan pembelajaran online serta munculnya teknologi digital sebagai media pembelajarannya (Bryan \& Volchenkova, 2016).

Implementasi Blended Learning yang menciptakan terobosan media pembelajaran yang terintegrasi dengan teknologi informasi dalam proses pembelajaran sudah banyak dikembangkan. Hendri (2014) yang memanfaatkan e-learning dengan aplikasi web 2.0 sebagai sarana pembelajaran pada perguruan tinggi menjelaskan bahwa web 2.0 merupakan website yang interaktif, yang memungkinkan pengguna tidak hanya dapat membaca informasi tetapi juga dapat menciptakan materi pembelajaran dan berinteraksi dengan orang lain. Selain itu, Harahap (2015) memberikan informasi mengenai pemanfaatan $e$ learning berbasis LCMS MOODLE sebagai media pembelajaran yang dapat meningkatkan kompetensi mahasiswa, serta Abar \& Carnevale (2019) mengembangkan Flipped Classrooms and MOODLE sebagai media pembelajaran yang diterapkan untuk mendukung kegiatan belajar dan mengajar Matematika menghasilkan informasi bahwa melalui Flipped Classrooms and MOODLE peserta didik tidak hanya mampu memanfaatkan ruang kelas sebagai tempat untuk memahami materi namun juga dapat berkembang menjadi suatu lingkungan yang memungkinkan terjadinya pertukaran pengalaman dan klarifikasi dari berbagai hal yang tidak diketahui sebelumnya.

Pembelajaran yang terintegrasi dengan teknologi informasi ini sangat penting diterapkan di Politeknik. Di Politeknik yang erat kaitanya dengan bidang industri, konsep Matematika merupakan salah satu subjek yang memiliki peranan penting untuk menunjang keberhasilan pencapaian pada bidang lainnya terutama dalam hal pengaplikasian Matematika dalam permasalahan praktis. Namun kenyataannya, berdasarkan hasil evaluasi mahasiswa diperoleh hasil bahwa lebih dari 50\% mahasiswa masih mengalami kesulitan dalam memahami konsep - konsep dasar yang menjadi modal dalam pembelajaran di Politeknik.

Berdasarkan hasil wawancara terhadap 5 orang mahasiswa diperoleh hasil bahwa ada beberapa faktor yang menjadi penghambat dari seorang mahasiswa dalam memahami konsep Matematika yaitu (1) Matematika dinggap sebagai objek yang sulit untuk dipelajari, (2) Motivasi belajar yang rendah; (3) Dosen masih menggunakan media whatsapp dan aplikasi sederhana lainnya sebagai penghubung informasi antara mahasiswa dan dosen sehingga pembelajaran menjadi kurang menarik dan interaktif serta kurang memicu mahasiswa untuk lebih memahami materi dengan baik; dan (4) Dosen kurang mengembangkan strategi, media 
dan model pembelajaran yang sesuai dengan karakteristik mahasiswa.

Salah faktor penghambat tersebut menjadi fokus dalam penelitian ini, yaitu media pembelajaran yang digunakan oleh dosen belum mampu menjadi sumber belajar yang menarik dan interaktif dalam upaya meningkatkan prestasi mahasiswa dalam bidang Matematika. Faktor penghambat ini apabila diacuhkan akan berdampak buruk terhadap kualitas pembelajaran serta kegagalan dalam pencapaian tujuan pembelajaran. Hal ini akan memperburuk kualitas lulusan sehingga akhirnya dapat berpengaruh terhadap kepercayaan dunia industri terhadap profil lulusan di Politeknik.

Salah satu solusi yang bisa dilakukan untuk menyelesaikan permasalahan ini adalah dengan menerapkan teknologi informasi dalam mengembangkan media pembelajaran. Pengembangan media belajar yang tepat dapat berfungsi secara efektif dan interaktif sebagai penghubung informasi antara mahasiswa dan dosen sehingga pencapaian kemandirian mahasiswa dalam menjalankan proses pembelajaran dapat tercapai dengan baik. Hal ini sejalan dengan pernyataan Handayani \& Rahayu (2020) bahwa dalam rangka mencapai keberhasilan pembelajaran yang optimal, maka diperlukan adanya sinkronisasi diantara tiga aspek utama dalam pembelajaran, yaitu guru, siswa dan media pembelajaran.

Farman \& Chairuddin (2020) menjelaskan bahwa e-learning adalah semua teknologi yang digunakan untuk mendukung upaya pembelajaran melalui internet. Melalui penelitian yang dilakukan oleh Maudiarti (2018) yang mengembangkan e-learning pada pembelajaran di Politeknik menjelaskan bahwa e-learning yang dikembangkan harus disesuaikan dengan karakteristik mahasiswa, lingkungan pendukung pembelajaran online, kemampuan Teknologi Informasi dan Komunikasi mahasiswa, tujuan pembelajaran, dan karakteristik ragam pengetahuan. Dari penelitian tersebut dipaparkan juga kesulitan sebagian besar dosen dalam memfasilitasi kelas virtual (pembelajaran online), khususnya dalam mengunggah (materi, tugas forum diskusi dan tes online).

Salah satu aplikasi yang mudah diintegrasikan dalam proses pembelajaran adalah MOODLE. Wahyuaji dkk ( 2019) menjelaskan . MOODLE adalah singkatan dari Modular Object Oriented Dynamic Learning Environment. MOODLE dapat diartikan sebagai alat yang dapat digunakan untuk membuat lingkungan pembelajaran yang dinamis dengan menampilkan sebuah media dalam bentuk website e-learning. MOODLE dapat diunduh melalui situs resminya yaitu http://MOODLE.org serta memiliki banyak tema dan plugin yang membuatnya mudah dikembangkan dan diaplikasikan. Menurut Abar \& Carnevale (2019), MOODLE memungkinkan dikembangkan sesuai dengan target audience dan memiliki karakteristik berbentuk kursus. Aplikasi ini juga dapat berfungsi sebagai content manager, digunakan untuk membuat bahan dan tugas yang tersedia dalam aplikasi dengan cara yang dinamis, menarik, dan inovatif. Dengan menggunakan MOODLE, dosen bisa mengunggah berbagai materi dengan beragam tipe seperti word, pdf, video, link youtube, hingga ujian online yang sangat mudah untuk diterapkan.

Berdasarkan kelebihan dari pembelajaran Blended Learning dan aplikasi MOODLE yang telah dipaparkan tersebut, maka tujuan 
penelitian ini adalah menghasilkan media pembelajaran Matematika model blended learning berbasis MOODLE yang dapat membantu lancarnya proses pembelajaran serta menguji kepraktisan media pembelajaran.

\section{METODE PENELITIAN}

Metode penelitian yang dilakukan dalam penelitian ini adalah metode penelitian dan pengembangan (Research and Development). Haryati (2012) menjelaskan bahwa dalam bidang pendidikan, produk-produk yang dihasilkan melalui penelitian $R \& D$ diharapkan dapat meningkatkan produktivitas pendidikan, yaitu lulusan yang jumlahnya banyak, berkualitas, dan relevan dengan kebutuhan. Penelitian ini menerapkan suatu proses atau langkah-langkah untuk mengembangkan suatu media pembelajaran model Blended learning berbasis MOODLE yang selanjutnya akan digunakan untuk kegiatan pembelajaran.

Untuk kegiatan desain dan pengembangan pembelajaran secara online menerapkan model ICCEE (Identification, Choose, Create, Engagement, Evaluation) yang dikembangkan oleh Chen (2016) seperti gambar 1 .

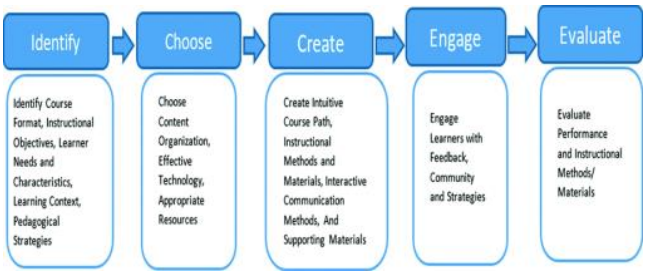

Gambar 1. Desain model pembelajaran online

Dalam merancang media pembelajaran Matematika model Blended Learning berbasis MOODLE digunakan model ICCEE yang dijabarkan sebagai berikut: (1)

Identifikasi (Identification), Langkah pertama dalam kegiatan perancangan media ini adalah menetapkan tujuan pembelajaran. Metode yang dipilih untuk diterapkan adalah metode Blended Learning. Metode pembelajaran Blended Learning merupakan metode pembelajaran yang mengintegrasikan teknologi informasi dalam penerapannya serta mengkombinasikan sistem pembelajaran tatap muka dan online. Langkah selanjutnya adalah mengidentifikasikan tujuan pembelajaran. Tujuan pembelajaran yang dirumuskan disesuaikan dengan metode yang dipilih serta karakteristik awal mahasiswa. Tahap akhir dari fase ini adalah mengidentifikasi strategi pedagogis yang tepat, dengan menerapkan teori belajar dan pembelajaran; (2) Memilih (Choose), Pada fase ini, dilakukan pemilihan tata letak organisasi konten yang berupa materi pembelajaran yang akan diberikan kepada mahasiswa secara online dan tatap muka. Pengaturan tata letak organisasi konten merupakan hal yang penting karena materi yang disajikan secara online harus diatur sedemikian rupa agar mahasiswa tetap merasa nyaman dalam belajar walaupun tidak secara tatap muka. Selanjutnya yang dilakukan adalah memilih alat teknologi efektif untuk memfasilitasi kegiatan belajar online . Dalam hal ini peneliti menggunakan MOODLE. Pemilihan aplikasi ini disesuaikan dengan keunggulan dari MOODLE. Berdasarkan data penelitian yang dilakukan oleh beberapa peneliti yang menggunakan aplikasi MOODLE, fasilitas ini mampu membantu dosen atau pengajar dalam mendukung kegiatan pembelajaran, karena faktor pendukung materi seperti video, gambar 
dan lainnya dapat dimasukkan kedalam sistem; (3) Membuat (Create), Pada fase ini, kegiatan yang dilakukan adalah membuat susunan atau aliran kursus, memilih metode pembelajaran yang akan digunakan, memilih materi untuk konten presentasi, tugas, dan penilaian, membuat metode komunikasi interaktif, dan membuat bahan pendukung bagi mahasiswa. Pada tahap ini kegiatan yang juga perlu dilakukan adalah dengan mengelompokkan kursus/materi pelajaran dengan tujuan untuk meningkatkan pembelajaran mahasiswa. Berikutnya mengembangkan bahan untuk presentasi konten pembelajaran, tugas, dan penilaian. Menyusun tugas dan umpan balik penilaian dibuat secara logis dan secara transparan sehingga mahasiswa yang ikut kegiatan pembelajaran online dapat melacak kemajuan mereka; (4) Keterlibatan (Engagement), Untuk mempertahankan dan keterlibatan mahasiswa mengikuti pembelajaran yang diberikan secara online menjadi penting yang tidak boleh dilupakan. Oleh karena itu dalam tahap implementasi secara online perlu fokus pada prosesnya tentang bagaimana melakukan pembelajaran online dan (5)

Evaluasi (Evaluation), Langkah terakhir dalam model ini adalah evaluasi. Penilaian yang akan diberikan kepada mahasiswa dilakukan secara holistik dan formatif serta disesuaikan dengan tuntutan era revolusi Industri 4.0. Unsur-unsur yang harus digali dari pembelajaran e-learning ini sejalan dengan yang dikemukakan oleh Puspitorini (2020) bahwa salah satu tujuan pembelajaran termasuk daring ini adalah pencapaian kompetensi peserta didik yang dikenal dengan $4 \mathrm{C}$, yaitu Critical thinking (berpikir kritis) yang mengarahkan peserta didik untuk untuk dapat menyelesaikan masalah (problem solving), Creativity thinking (berpikir kreatif) dapat dimaknai dosen bisa mendampingi peserta didik yang memiliki kreativitas tinggi mampu berpikir dan melihat suatu masalah dari berbagai sisi atau perspektif. Dalam kegiatan evaluasi kinerja mahasiswa dilakukan dengan berbagai strategi, seperti proyek, presentasi, tugas, tes, keterlibatan dan keaktifan mahasiswa pada pembelajaran online juga dievaluasi secara progresif dan berkala. Selanjutnya hal yang juga perlu dilakukan adalah mengevaluasi efektivitas metode dan materi pembelajaran yang diberikan, dengan tujuan untuk memperbaiki proses serta materi yang akan diberikan untuk kegiatan berikutnya.

Penelitian ini dilakukan di Politeknik Manufaktur Negeri Bangka Belitung. Subjek penelitian dalam penelitian ini adalah 55 orang mahasiswa mahasiswa tingkat 1 Jurusan Teknik Mesin Politeknik Manufaktur Negeri Bangka Belitung yang memiliki kemampuan yang beragam.

Hobri (2010) menyatakan bahwa suatu media pembelajaran dikatakan berkualitas jika memenuhi aspek-aspek validitas, kepraktisan, dan keefektifan. Dengan demikian, media yang telah dirancang dilanjutkan dengan proses validasi oleh ahli. Tahap validasi isi dilakukan untuk melihat pemenuhan aspek penyajian, isi dan Bahasa (Mardia \& Sundara, 2020). Handayani \& Rahayu menjelaskan bahwa tahap validasi ahli dilakukan dengan memperbaiki/merevisi media tersebut (revisi desain) berdasarkan masukkan dari para ahli. Jika media sudah memenuhi kriteria dan tidak perlu ada perbaikan lagi maka media siap untuk diujicobakan pada pengguna (mahasiswa). Sehingga dapat disimpulkan bahwa media tersebut valid dari segi konten. Masukan yang 
diberikan oleh ahli digunakan sebagai bahan masukan untuk revisi media sebelum diujicobakan kepada mahasiswa. Instrumen pengumpulan data yang digunakan dalam penelitian ini adalah Lembar angket Validasi ahli yang berisi aspek-aspek yang perlu diamati oleh ahli dalam proses penilaiannya. Hal ini dilakukan agar unsur -unsur utama yang perlu ditonjolkan dari media pembelajaran Matematika model Blended Learning berbasis MOODLE ini dapat teramati semua oleh ahli.

Tahap validasi ahli ini dilakukan oleh dua orang ahli dalam bidang Pendidikan Matematika yaitu Dr. Risnina Wafiqoh dan Fitri Aprianti, M.Pd. Keduanya merupakan dosen Pendidikan Matematika di Universitas Muhammadiyah Bangka Belitung.

Setelah mendapatkan hasil dari ahli bahwa media yang dikembangkan sudah valid dari segi konten,kegiatan selanjutnya dilanjutkan dengan kegiatan ujicoba penggunaan media terhadap mahasiswa. Kegiatan ujicoba kepada mahasiswa ini dilakukan untuk mendapat kesimpulan bahwa media pembelajaran Matematika model Blended Learning berbasis MOODLE ini memiliki kriteria praktis.

Tahap pengujian kepraktisan media yang dikembangkan dilakukan dengan tahapan yang dilakukan oleh Widyasari (2019), yaitu : (1) uji coba satu-satu; (2) uji coba kelompok kecil dengan 13 mahasiswa; dan (3) uji coba lapangan dengan seluruh mahasiswa tingkat I jurusan Teknik Mesin sejumlah 55 orang. Uji coba ini dilakukan dengan menggunakan angket uji kepraktisan yang berupa pernyataanpernyataan yang akan dinilai oleh mahasiswa setelah mereka mencoba menggunakan media pembelajaran
Matematika model Blended Learning berbasis MOODLE ini.

Data yang diperoleh dari angket selanjutnya dianalsis untuk memperoleh kesimpulan yang diperlukan untuk penelitian ini. Penilaian kepraktisan media pembelajaran berbasis MOODLE dalam penelitian dan pengembangan ini ditentukan dengan nilai rata-rata lebih dari 60 yaitu kategori Praktis.

\section{HASIL DAN PEMBAHASAN}

Penelitian dan pengembangan media pembelajaran Matematika model blended learning berbasis MOODLE ini dikembangkan diawali dengan proses perancangan media yang diterapkan dengan menggunakan model ICCEE yang telah dijelaskan pada bagian metode penelitian. Selanjutnya media pembelajaran Matematika model blended learning berbasis MOODLE ini divalidasi oleh ahli dari segi konten. Media pembelajaran Matematika Model Blended Learning Berbasis MOODLE yang dikembangkan mengalami beberapa perbaikan dari tahap validasi ahli. Saran dan masukan dari ahli menjadi bahan perbaikan untuk prototype 1 sebagai langkah validasi awal untuk menghasilkan prototype 2 .

Setelah media pembelajaran Matematika Model Blended Learning Berbasis MOODLE ini dinyatakan sudah valid dan bisa digunakan untuk tahap uji coba kepada mahasiswa, barulah tahap uji coba kepada mahasiswa dilakukan. Media Pembelajaran Model Blended Learning Berbasis MOODLE yang sudah melalui proses validasi ahli, diujicobakan kepada 13 orang mahasiswa untuk melihat kepraktisan media pembelajaran yang sudah dikembangkan. Adapun rata-rata skor yang diperoleh dari hasil analisis untuk kelompok kecil ditunjukan pada Tabel 1 
DOI: https://doi.org/10.24127/ajpm.v10i1.3240

Tabel 1. Rekapitulasi hasil uji coba media pada kelompok kecil

\begin{tabular}{cc}
\hline Jumlah Responden & Rata-rata skor \\
\hline 13 & 78,20
\end{tabular}

Berdasarkan skor rata-rata uji kepraktisan media kelompok kecil yang dijelaskan dalam metode penelitian, kualitas media pembelajaran Model Blended Learning Berbasis MOODLE ini termasuk kategori praktis karena berada pada rentang $61-80$. Hal ini mengartikan bahwa Media Pembelajaran Model Blended Learning Berbasis MOODLE yang dikembangkan dapat dilanjutkan pada uji kepraktisan pada kelompok besar.

Sedangkan hasil analisis terhadap kelompok besar yang dilakukan terhadap 55 mahasiswa memberikan hasil seperti yang ditunjukkan pada tabel 2 .

Tabel 2. Rekapitulasi hasil uji coba media pada kelompok besar
Berdasarkan skor rata-rata uji kepraktisan media kelompok besar yang dijelaskan dalam metode penelitian, kualitas media pembelajaran Model Blended Learning Berbasis MOODLE ini termasuk kategori praktis karena berada pada rentang $61-80$. Hal ini menunjukkan bahwa Media Pembelajaran Model Blended Learning Berbasis MOODLE yang dikembangkan praktis untuk digunakan dalam proses pembelajaran Matematika di Politeknik Manufaktur Negeri Bangka Belitung. Media pembelajaran ini akan diterapkan dalam pembelajaran Mata Kuliah Matematika 1 di Politeknik Manufaktur Negeri Bangka Belitung.

Tahap selanjutnya adalah tahap implementasi media pembelajaran Model Blended Learning Berbasis MOODLE dimana media ini diterapkan pada pembelajaran di kelas sebanyak 3 kali pertemuan online dan 1 kali pertemuan offline dengan materi Bilangan dan Aplikasi Bangun Ruang pada bidang Keteknikan.

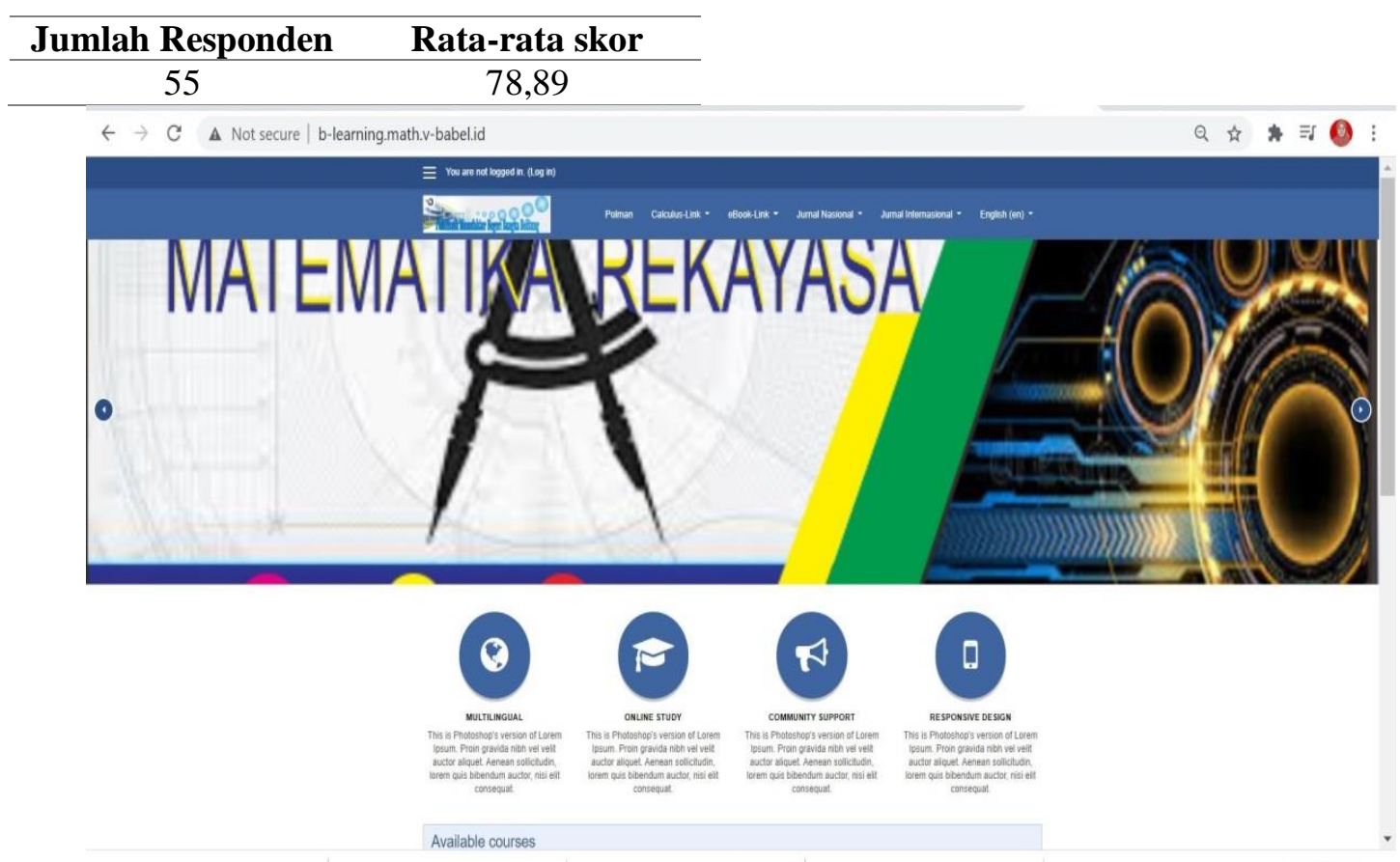

Gambar 2. Tampilan utama link http://b-learning.math.v-babel.id/ 
DOI: https://doi.org/10.24127/ajpm.v10i1.3240

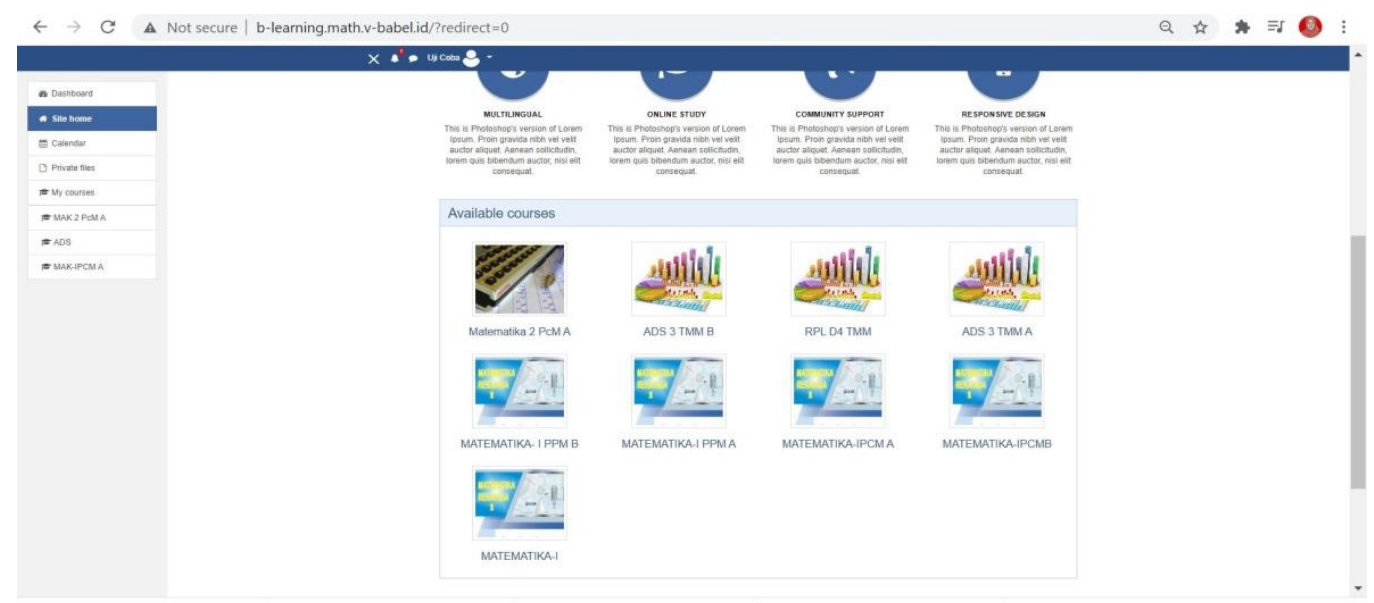

Gambar 3. Tampilan setelah mahasiswa log in

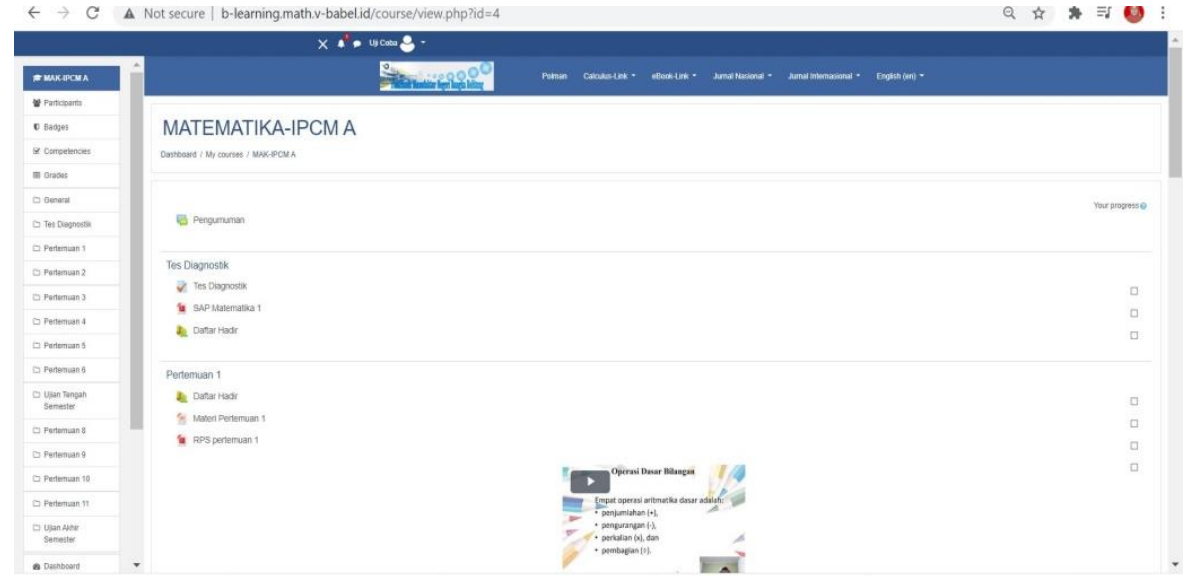

Gambar 4. Tampilan MOODLE kelas Matematika

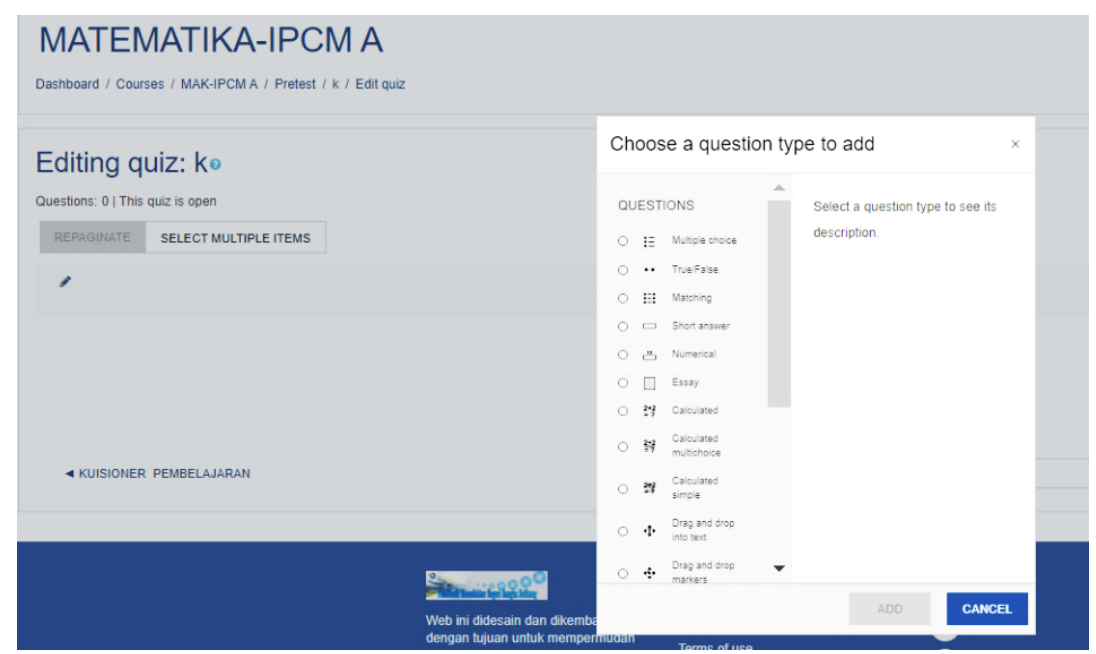

Gambar 5. Tipe-tipe pertanyaan yang bisa dipilih 
DOI: $\underline{\text { https://doi.org/10.24127/ajpm.v10i1.3240 }}$

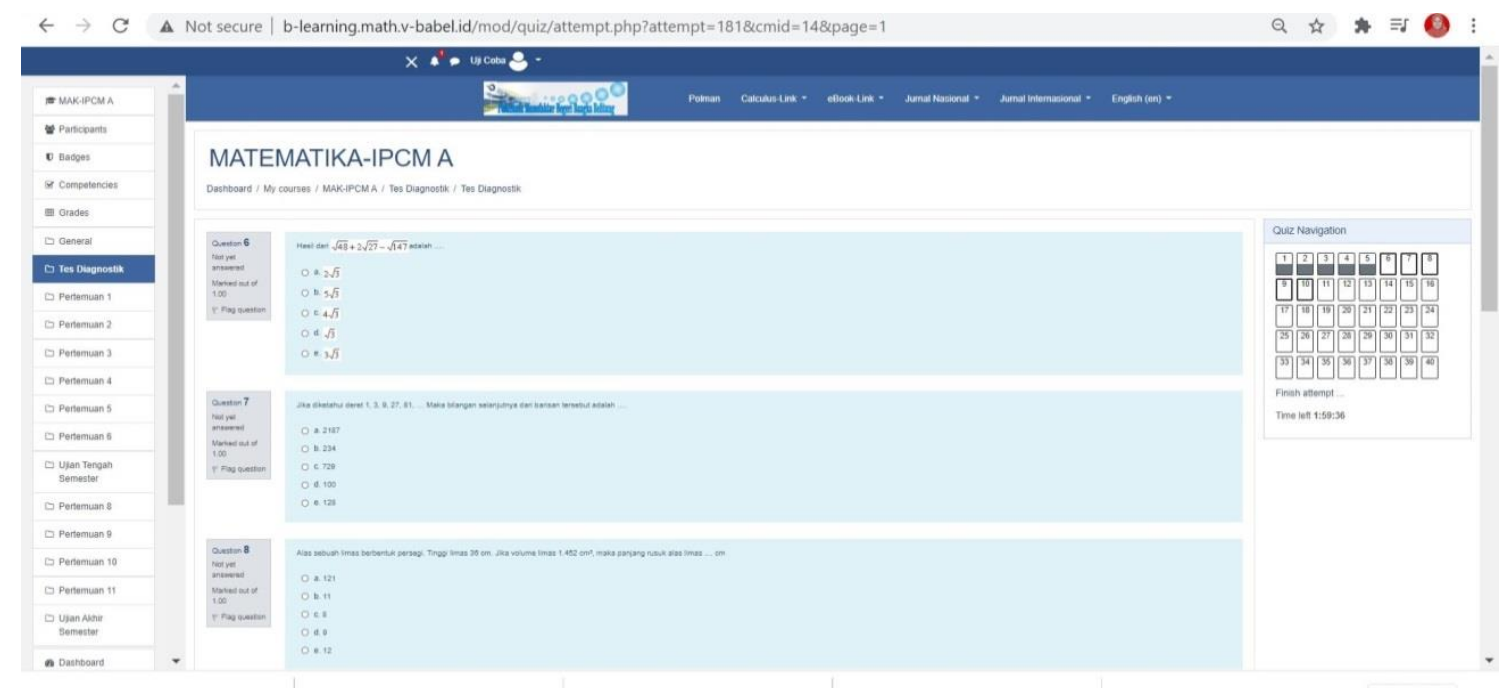

Gambar 6. Tampilan tes online matematika tipe multiple choice

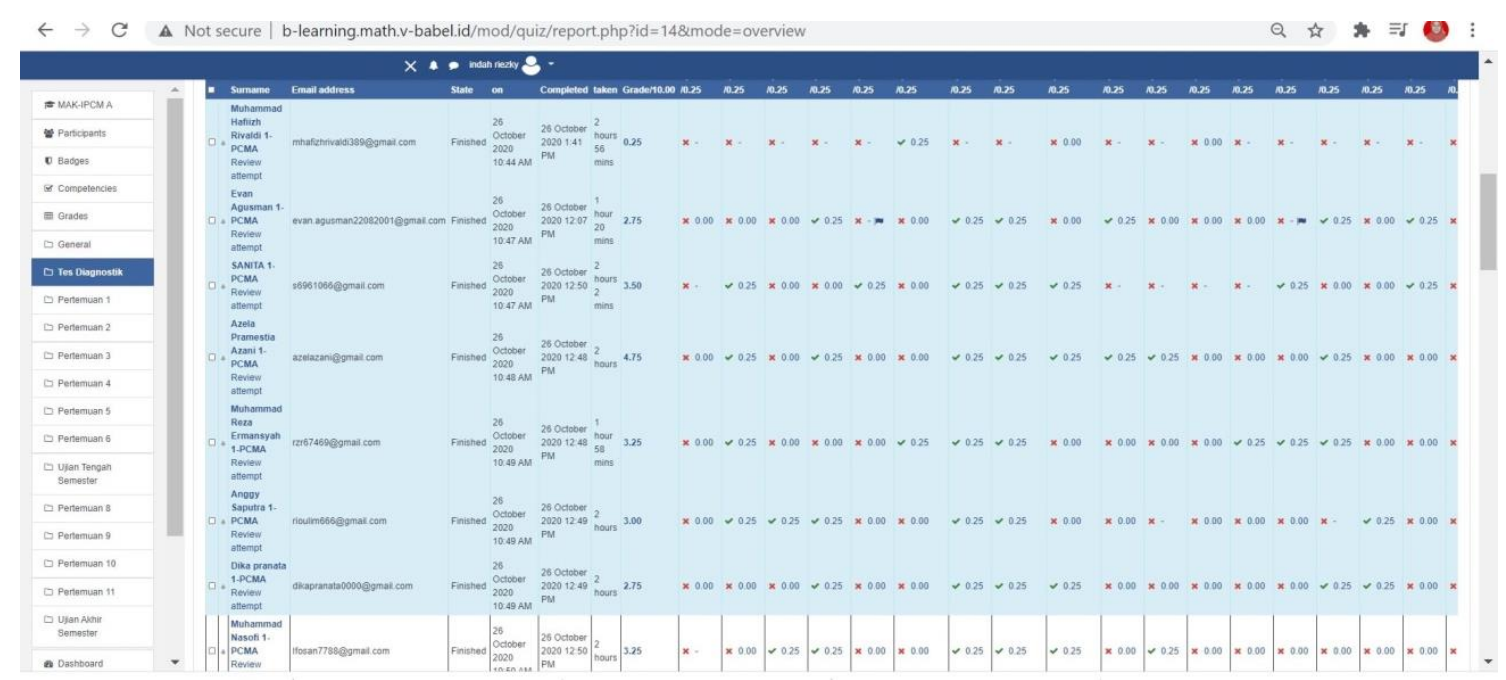

Gambar 7. Tampilan hasil tes online

Media pembelajaran Model Blended Learning berbasis MOODLE nya bisa di akses pada link http://blearning.math.v-babel.id/. Ketika mahasiswa mengakses link http://blearning.math.v-babel.id/, mahasiswa akan diminta memasukkan username dan password. Adapun beberapa tampilan media pembelajaran dapat dilihat pada Gambar 2.

Setelah log in, mahasiswa akan masuk kedalam kelasnya masingmasing. Username dan password mahasiswa yang sebelumnya telah diberikan oleh dosen. Selanjutnya mahasiswa bisa membuka materi yang ada pada kelas MOODLE tergantung dengan keterangan untuk materi pertemuan ke berapa. Materi yang diinput berupa PPT dan PDF yang dapat mahasiswa download dengan cara mengklik pada tulisannya.

Selain itu, pada MOODLE juga bisa diinput link youtube agar dosen bisa menampilkan video pembelajaran yang telah direkam sebelumnya untuk dapat diamati oleh mahasiswa. Ketika mahasiswa berhasil men-download 
materi, file akan tersimpan otomatis di perangkat belajarnya. Ada banyak kemudahan yang bisa dirasakan oleh dosen melalui penggunaan MOODLE ini, terutama dalam pelaksanaan tes online nya. Ada beberapa jenis pertanyaan yang bisa diinput pada MOODLE, seperti yang ditunjukkan pada Gambar 5.

Waktu pengerjaan tes online juga bisa diatur oleh dosen, sehingga ketika waktu pengerjaan sudah mencapai limit, maka laman tes akan tertutup otomatis dan hasil pengerjaan mahasiswa akan tersimpan ke dalam data MOODLE yang selanjutnya dapat dinilai oleh dosen. Selanjutnya Gambar 6 menunjukkan tampilan tes online yang sudah diinput dosen pada MOODLE. Item soal yang akan digunakan pada media dapat dimasukkan langsung dengan menggunakan fitur yang ada atau juga bisa disusun terlebih dahulu dengan menggunakan aplikasi Exam View baru kemudian diupload ke dalam media. Tes online pada Gambar 6 menggunakan jenis multiple choice question.

Gambar 7 menunjukkan tampilan hasil tes online yang bisa dilihat pada akun dosen. Dari gambar 7 terlihat bahwa data langsung dapat memunculkan poin mahasiswa per soal, dan nilai akhir yang diperoleh oleh mahasiswa. Selanjutnya data di atas bisa di-download oleh dosen dalam bentuk excel sehingga bisa disimpan diperangkat kerja dosen.

Penggunaan media pembelajaran dengan model blended learning berbasis moodle sangat mempermudah proses pembelajaran. Banyak sekali aplikasi yang bisa terintegrasi langsung pada Moodle ini, salah satunya adalah Zoom Meeting yang bisa diatur oleh dosen mengenai penjadwalannya.
Sebelum memulai pembelajaran, dosen sudah memasukan berbagai materi yang berkaitan dengan topik bahasan yang akan dipelajari. Dalam hal ini dosen menginput materi dalam bentuk word, $p d f$, ppt, serta video yang sebelumnya sudah dosen buat melalui Laman Youtube. Pada tahap implementasi juga dilakukan pemberian angket respon mahasiswa terhadap penggunaan Media Pembelajaran dengan Model Blended Learning Berbasis MOODLE yang dikembangkan. Analisis respon mahasiswa terhadap penggunaan media ditinjau dari aspek ketertarikan, kemudahan penggunaan, kemanfaatan media dan perhatian mahasiswa selama penggunaan media.

Tabel 3. Hasil respon peserta didik

\begin{tabular}{ccc}
\hline $\begin{array}{c}\text { Respon } \\
\text { Mahasiswa }\end{array}$ & $\begin{array}{c}\text { Jumlah } \\
\text { Mahasiswa }\end{array}$ & Rerata \\
\cline { 2 - 3 } & 55 & 79,92 \\
\hline
\end{tabular}

Tabel 1 menunjukkan bahwa rerata respon kelas peserta didik terhadap media pembelajaran adalah 78,89 dan berada pada kriteria praktis. Media pembelajaran yang dikembangkan ini tergolong praktis Setelah pengguna menyatakan media mudah digunakan, mudah dipahami, dan instruksinya mudah dimengerti. Pengguna tidak merasa kesulitan dalam penggunaannya, maka media dinyatakan praktis. Selanjutnya berdasarkan analisis data hasil belajar peserta didik materi Bilangan diperoleh rata-rata 79,92 dan jumlah mahasiswa yang mencapai nilai diatas 70 adalah sebanyak 44 orang mahasiswa (80\%). Secara ringkas hasil belajar materi Bilangan disajikan pada Tabel 2. 
DOI: https://doi.org/10.24127/ajpm.v10i1.3240

Tabel 2. Hasil belajar materi bilangan

\begin{tabular}{lc}
\hline \multicolumn{1}{c}{ Hasil Belajar } & Skor \\
\hline Nilai Tertinggi & 100 \\
Nilai Terendah & 42 \\
Rerata & 78,23 \\
Persentase & $80 \%$ \\
Ketuntasan & \\
\hline
\end{tabular}

Media Pembelajaran dengan Model Blended Learning Berbasis MOODLE ini memiliki beberapa kelebihan yang sangat berperan penting sebagai penunjang pembelajaran di era Revolusi Industri 4.0 dimana mahasiswa dapat belajar dimanapun dan kapanpun tanpa ada batas ruang dan waktu. Media Pembelajaran dengan Model Blended Learning Berbasis MOODLE ini memiliki kelengkapan fitur yang bisa digunakan oleh mahasiswa dan dosen dalam kegiatan pembelajar. MOODLE ini memiliki beberapa media komunikasi yang bisa dimanfaatkan oleh mahasiswa dan dosen seperti chatting, messaging, dan forum. Selain itu, melalui aplikasi MOODLE ini, dosen bisa memantau kegiatan pembelajaran (Tracking data) yang sedang dilakukan mahasiswa dari mulai Log in hingga Log out. Kemudahan penggunaan Media Pembelajaran dengan Model Blended Learning Berbasis MOODLE ini juga dapat dirasakan untuk penggunaannya pada proses evaluasi. Aplikasi MOODLE dapat menampung tugas mahasiswa melalui fitur Assignment sehingga data dapat terorganisir dengan baik dan memudahkan mahasiswa dan dosen dalam memantau hasil evaluasi belajar mereka. Nilai mahasiswa untuk setiap tugas juga bisa dilihat di aplikasi MOODLE ini pada bagian Grade.

Kesulitan pemahaman yang biasanya mahasiswa temui dari pembelajaran offline dapat diatasi melalui video pembelajaran yang diinput dosen di media MOODLE.
Dimanapun dan kapanpun, mahasiswa bisa mengulang materi hingga materi dapat dipahami dengan baik. Melalui Media Pembelajaran dengan Model Blended Learning Berbasis MOODLE ini keterbatasan pembelajaran online bisa teratasi sehingga prestasi belajar mahasiswa bisa kembangkan melalui media pembelajaran ini.

Selain memberikan berbagai kemudahan, aplikasi MOODLE juga memperoleh kekurangan yang teramati dalam tahap implementasi ini, yaitu pada pilihan Bahasa yang ada pada beberapa bagian tampilan MOODLE yang tidak bisa diubah, sehingga untuk mahasiswa yang memiliki keterbatasan kemampuan Bahasa Inggris harus lebih berusaha memahami lagi.

Penelitian ini sejalan dengan penelitian Hendri (2014), Harahap (2015), Abar \& Carnevale (2019), serta Maudiarti (2018) yang memaparkan mengenai berbagai kemudahan yang dapat dirasakan melalui penggunaan $e$ learning MOODLE dalam proses pembelajaran. Mahasiswa yang belajar dengan MOODLE menghasilkan pemahaman yang baik tentang materi Matematika. Video yang dimasukkan di MOODLE sebagai bahan belajar mampu membantu peserta didik ketika menemui kesulitan dalam pemahaman konsep dan kelebihannya bisa diulang berkali-kali sebanyak yang mereka mau untuk memperkuat pemahaman konsep.

Berdasarkan berbagai manfaat dan kemudahan yang dapat dirasakan dari penggunaan Media Pembelajaran dengan Model Blended Learning Berbasis MOODLE ini, pendidik di sekolah menengah maupun pada perguruan tinggi dapat menerapkan media pembelajaran ini untuk menunjang kegiatan pembelajaran. Media Pembelajaran dengan Model Blended Learning Berbasis MOODLE 
ini juga dapat dikaji kembali mengenai kemampuan kognitif dan afektif yang bisa dikembangkan melalui penelitian selanjutnya.

\section{KESIMPULAN DAN SARAN}

Berdasarkan hasil penelitian dapat disimpulkan bahwa media pembelajaran Matematika model blended learning berbasis MOODLE yang dikembangkan tergolong kategori valid dari segi konten. Selain itu, media pembelajaran Matematika model blended learning MOODLE yang dikembangkan tergolong kategori praktis. Saran untuk penelitian selanjutnya dapat diujicoba efektifitas dari media pembelajaran ini.

\section{DAFTAR PUSTAKA}

Abar, C. A. A. P., \& Carnevale de Moraes, U. (2019). Flipped Classrooms and MOODLE: Digital Technologies to Support Teaching and Learning Mathematics. Acta Didactica Napocensia, 12(2), 209216.https://doi.org/10.24193/adn.1 2.2 .16

Bryan, A., \& Volchenkova, K. N. (2016). Blended Learning: Definition, Models, Implications for Higher Education. Bulletin of the South Ural State University Series "Education. Education Sciences," 8(2), 24-30. https://doi.org/10.14529/ped16020 4

Chen, L.-L. (2016). A Model for Effective Online Instructional Design. Literacy Information and Computer Education Journal, 7(2). https://doi.org/10.20533/licej.2040. 2589.2016.0304

Farman, F., \& Chairuddin, C. (2020). Pengembangan Media E-Learning Berbasis Edmodo Pada Materi Teorema Pythagoras. AKSIOMA:
Jurnal Program Studi Pendidikan Matematika, 9(4), 872. https://doi.org/10.24127/ajpm.v9i4. 3114

Handayani, D., \& Rahayu, D. V. (2020). Pengembangan Media Pembelajaran Interaktif Berbasis Android Menggunakan Ispring Dan Apk Builder Untuk Pembelajaran Matematika Kelas X Materi Proyeksi Vektor. MA TH L I $N$ E Jurnal Matematika Dan Pendidikan Matematika, 5(1), 1225.

https://doi.org/10.31943/mathline.v $5 \mathrm{i} 1.126$

Harahap, S. H. (2015). Pemanfaatan ELearning Berbasis Lcms MOODLE Sebagai Media Pembelajaran Untuk Mata Kuliah Sistem Informasi Akuntansi. Jurnal Riset Akuntansi dan Bisnis, 15(1), 14.

Haryati, S. (2012). Research and Development (R\&D) Sebagai Salah Satu Model Penelitian dalam Bidang Pendidikan. Research And Development (R\&D) Sebagai Salah Satu Model Penelitian Dalam Bidang Pendidikan, 37(1), 11-26.

Hendri. (2017). Pemanfaatan Elearning Dengan Aplikasi Web 2.0 Sebagai Sarana Pembelajaran Pada Perguruan Tinggi Di Indonesia. Jurnal Ilmiah Media Processor, 9(2), 150-156.

Hobri, H. (2010). Metodologi penelitian pengembangan (aplikasi pada penelitian pendidikan matematika). Jember: Pena Salsabila.

Mardia, A., \& Sundara, V. Y. (2020). Pengembangan Modul Program Linier Berbasis Pembelajaran Mandiri. Edumatica: Jurnal 
DOI: https://doi.org/10.24127/ajpm.v10i1.3240

Pendidikan Matematika, 10(01), 918.

Puspitorini, F. (2020). Strategi

Pembelajaran Di Perguruan Tinggi

Pada Masa Pandemi Covid-19.

Jurnal Kajian Ilmiah, 1(1), 99106.

https://doi.org/10.31599/jki.v1i1.2 74

Sahni, J. (2019). Does Blended Learning Enhance Student Engagement? Evidence from Higher Education. Journal of ELearning and Higher Education, 2019, 1-14. https://doi.org/10.5171/2019.12151 8

Wahyuaji, N. R., \& Taram, A. (2019). Pengembangan Media Pembelajaran Matematika Berbasis E-Learning Menggunakan Learning Management System (LMS) MOODLE pada Materi Program Linear untuk Siswa SMA Kelas XI. Seminar Nasional Pendidikan Matematika Ahmad Dahlan, 6(May), 189-194. http://seminar.uad.ac.id/index.php/ sendikmad/article/view/407
Widyasari Nurbaiti, P. E. (2019). Pengembangan Bahan Ajar Number Bonds Untuk Siswa Kelas 1 Sekolah Dasar. PEDADIDAKTIKA: Jurnal Ilmiah Pendidikan Guru Sekolah Dasar, 5(3), 276-286.

Wijayanti, W., Maharta, N., \& Suana, W. (2017). Pengembangan Perangkat Blended Learning Berbasis Learning Management System pada Materi Listrik Dinamis. Jurnal Ilmiah Pendidikan Fisika Al-Biruni, 6(1), 1. https://doi.org/10.24042/jpifalbirun i.v6i1.581 